\title{
Responses of nitrogen stable isotopes in fish to phosphorus limitation in freshwater wetlands
}

\author{
Jianming Hong ${ }^{1}$ and Binhe $\mathrm{Gu}^{2, *}$ \\ ${ }^{1}$ College of Life Sciences, Capital Normal University, Beijing, 100048, China \\ ${ }^{2}$ Soil and Water Science Department, University of Florida, 106 Newell Hall, Gainesville, FL 32611, USA
}

Received: 28 May 2020 / Accepted: 30 September 2020

\begin{abstract}
Human-induced eutrophication has altered ecological processes in aquatic ecosystems. Detection of ecological changes is a prerequisite for protecting ecosystems from degradation. In this study, nitrogen stable isotopes $\left(\delta^{15} \mathrm{~N}\right)$ in fish are evaluated as indicators of environmental changes in south Florida wetlands. Stable nitrogen isotope $\left(\delta^{15} \mathrm{~N}\right)$ data of select fish species and water quality collected from the Florida Everglades between the 1990s and 2000s were used to assess the relationship between total phosphorus concentrations and $\delta^{15} \mathrm{~N}$ ratios. The $\delta^{15} \mathrm{~N}$ ratios in nine of ten select fish species increase significantly as total phosphorus concentration in the surface water increases. There were significant relationships between total nitrogen concentration in the surface water and $\delta^{15} \mathrm{~N}$ ratios in several fish species. The pattern of changes in $\delta^{15} \mathrm{~N}$ ratios along nutrient gradients suggests that increased eutrophication is recorded as the $\delta^{15} \mathrm{~N}$ ratios in fish. The lack of human wastewater loading, the dominance in agricultural runoff and the high TN:TP ratio suggest that phosphorus is the limiting factor driving ecosystem productivity and the changes of $\delta^{15} \mathrm{~N}$ ratios in fish. Results from this analysis demonstrate that $\delta^{15} \mathrm{~N}$ ratios in fish integrate biotic responses to eutrophic process over time and could be a robust indicator for early ecological changes.
\end{abstract}

Keywords: Eutrophication / Everglades / Fish / Nitrogen / Nutrient gradient / Phosphorus / Stable nitrogen isotopes / Wetlands

\begin{abstract}
Résumé - Réponses des isotopes stables de l'azote chez les poissons à la limitation du phosphore dans les zones humides d'eau douce. L'eutrophisation d'origine humaine a altéré les processus écologiques des écosystèmes aquatiques. La détection des changements écologiques est une condition préalable à la protection des écosystèmes contre la dégradation. Dans cette étude, les isotopes stables de l'azote $\left(\delta^{15} \mathrm{~N}\right)$ chez les poissons sont évalués comme indicateurs des changements environnementaux dans les zones humides du sud de la Floride. Les données sur les isotopes stables de l'azote $\left(\delta^{15} \mathrm{~N}\right)$ de certaines espèces de poissons et sur la qualité de l'eau recueillies dans les Everglades de Floride entre les années 1990 et 2000 ont été utilisées pour évaluer la relation entre les concentrations de phosphore total et les rapports $\delta^{15} \mathrm{~N}$. Les rapports $\delta^{15} \mathrm{~N}$ de neuf des dix espèces de poissons sélectionnées augmentent de manière significative lorsque la concentration de phosphore total dans les eaux de surface augmente. On a constaté des relations significatives entre la concentration d'azote total dans les eaux de surface et les rapports $\delta^{15} \mathrm{~N}$ chez plusieurs espèces de poissons. Le schéma des changements des rapports $\delta^{15} \mathrm{~N}$ le long des gradients de nutriments suggère qu'une eutrophisation accrue est enregistrée dans les rapports $\delta^{15} \mathrm{~N}$ chez les poissons. L'absence de charge en eaux usées, la prédominance du ruissellement agricole et le rapport élevé TN:TP suggèrent que le phosphore est le facteur limitant qui détermine la productivité des écosystèmes et les changements des rapports $\delta^{15} \mathrm{~N}$ chez les poissons. Les résultats de cette analyse montrent que les rapports $\delta{ }^{15} \mathrm{~N}$ chez les poissons intègrent les réponses biotiques au processus d'eutrophisation au fil du temps et pourraient être un indicateur robuste des premiers changements écologiques.
\end{abstract}

Mots-clés : Eutrophisation, Everglades, Poissons / Azote, Gradient de nutriments / Phosphore / Isotopes d'azote stables / Zones humides

\footnotetext{
*Corresponding author: gubinhe@gmail.com
} 


\section{Introduction}

A number of environmental indicators have been used to assess ecological processes in aquatic ecosystems. Current indicators of environmental changes for freshwater include nutrient loading such as soil and water total phosphorus (TP), total nitrogen (TN) concentrations, biodiversity and primary productivity (Jeppesen and Sammalkorpi, 2002). These indicators often reveal the changes in the impacted systems at the basal resource levels (nutrients and primary producers). Identification of signs of environmental change along higher trophic levels in aquatic food webs is critical for the restoration of disturbed systems and wildlife protection (Vander Zanden et al., 2005).

Nitrogen stable isotope compositions of organic matter may be a complementary means to detect environmental changes in aquatic ecosystems. The ratios of ${ }^{15} \mathrm{~N} /{ }^{14} \mathrm{~N}$ (defined as $\delta^{15} \mathrm{~N}$ ) may provide insight into the sources, sinks and cycling of nitrogen in biota that interact with their physical and chemical environments (Peterson and Fry, 1987). The use of $\delta^{15} \mathrm{~N}$ as an indicator of aquatic eutrophication is based on the fact that increases in ecosystem productivity controlled by nutrient enrichments will lead to decreases in isotope fractionation by primary producers and the transfers of organic matter from one trophic level to another will result in predictable isotope enrichment along food chain (Post, 2002; Vander Zanden et al., 2015). At present, the use of consumer $\delta^{15} \mathrm{~N}$ largely focuses on the source of nitrogen contaminations (Lake et al., 2001; Vander Zanden et al., 2005; Schlacher et al., 2005; Robinson et al., 2016; Souza et al., 2018) and trophic interactions (Post, 2002; Vander Zanden et al., 2015; Wang et al., 2018). Very few studies link consumer isotope composition to primary productivity in freshwater ecosystems (Woodland et al., 2012; Hou et al., 2013).

In this study, we compared $\delta^{15} \mathrm{~N}$ ratios in 10 species of freshwater fish collected along a nutrient gradient in the Everglades, Florida, USA. The purposes of this study were (1) to understand the responses and mechanisms controlling the isotope variations along the nutrient gradient, and (2) to evaluate if fish $\delta^{15} \mathrm{~N}$ is a reliable and feasible candidate for human-induced eutrophication in freshwater wetlands. This study provides insight into isotopic responses to changing water quality.

\section{Materials and methods}

\subsection{Site description}

The Everglades is the largest subtropical peatland in the United States with its historic geochemistry and biological community characterizing an oligotrophic ecosystem (Wright et al., 2008; Richardson, 2010). Since human settlement, a large portion of the Everglades peatland immediately south of Lake Okeechobee was converted into farmlands, i.e., Everglades Agricultural Area (EAA). The remaining Everglades has been divided by drainage canals, levees and water control structures into three Water Conservation Areas (WCA-1, WCA-2 and WCA-3), and Everglades National Park (ENP). Discharge of EAA runoff which contains high concentrations of total phosphorus (TP) and total nitrogen (TN) has led to cattail (Typha spp.) invasion and replacement of the native macrophytes and periphyton (Sklar et al., 2005). Increased P loads in surface water runoff have shifted portions of the ecosystem from oligotrophic to eutrophic states. As a result, TP and TN concentrations in the water column and soil near the inflow regions are elevated (Wright et al., 2008).

\subsection{Sources of data}

Stable isotope data on fish collected from 1994 to 1999 were downloaded from the United States Geological Survey South Florida Information Access (Appendix Tab. A1). A total of 16 sites, with three sites in Stormwater Treatment Area-1 West (STA-1W) and 13 sites in the WCAs and ENP (Fig. 1) were sampled, often on multiple field trips. These sites include canals, near levee inflow and outflow structures and interior marshes. Fish were caught randomly and brought to a laboratory where muscle tissue from each fish was removed, dried and ground to fine powder for stable isotopes analysis. Additional samples of mosquitofish were collected along the nutrient gradient in WCA-2A in 2007 (Fig. 1 and Tab. 1). Muscle tissue from 3 to 5 mosquitofish was composed into a single sample per site and processed as above prior to stable isotope analysis.

Select environmental data were downloaded from DBHYDRO, a hydrometeorologic, water quality, and hydrogeologic data retrieval system managed by the South Florida Water Management District (West Palm Beach Florida, USA). Water quality data recorded one year before fish collection date were averaged to reflect environmental conditions of each habitat. When environmental data were not available from the same fish collection site, data from closely located sites were used.

Fish samples collected in the 1990s were analyzed for stable isotopic composition $\left(\delta^{13} \mathrm{C}\right.$ and $\left.\delta^{15} \mathrm{~N}\right)$ using a Micromass Optima continuous flow mass spectrometer coupled to a Carlo Erba elemental analyzer at US Geological Survey. Results are reported in the usual delta notation relative to V-PDB for ${ }^{13} \mathrm{C}$ and air for ${ }^{15} \mathrm{~N}$. Analytical precision $(1 \sigma)$ based on repeat analysis of both samples was generally in the range of $0.1-0.2 \%$ for both $\mathrm{C}$ and $\mathrm{N}$, but for some samples replication was no better than $\pm 0.5 \%$ due to sample heterogeneity (Kendall et al., 2005). Mosquitofish samples collected in 2007 were analyzed using a Carlo Erba Elemental Analyzer interfaced to a Finnigan MAT Delta Plus XP stable isotope ratio mass spectrometer (IRMS) at Florida State University. The precision of the $\mathrm{C}$ and $\mathrm{N}$ isotope analysis was $\pm 0.2 \%$ o $(1 \sigma)$ or better on the basis of repeated analysis of different laboratory standards.

\subsection{Statistics}

Because not all fish were found in each site, only fish found in at least 6 sites were used in this analysis. Ten species belonging to different trophic levels met this criterion. The $\delta{ }^{15} \mathrm{~N}$ ratios of select fish species from different years of collection were pooled from a given site (Appendix Tab. A1). Spearman Rank Correlation analysis was used to establish relationships between TP, TN and molar TN:TP ratios and $\delta^{15} \mathrm{~N}$ of each fish species. All statistics were performed using SAS JMP (Version 7, SAS Institute). Statistics were considered significant at $P<0.05$. 


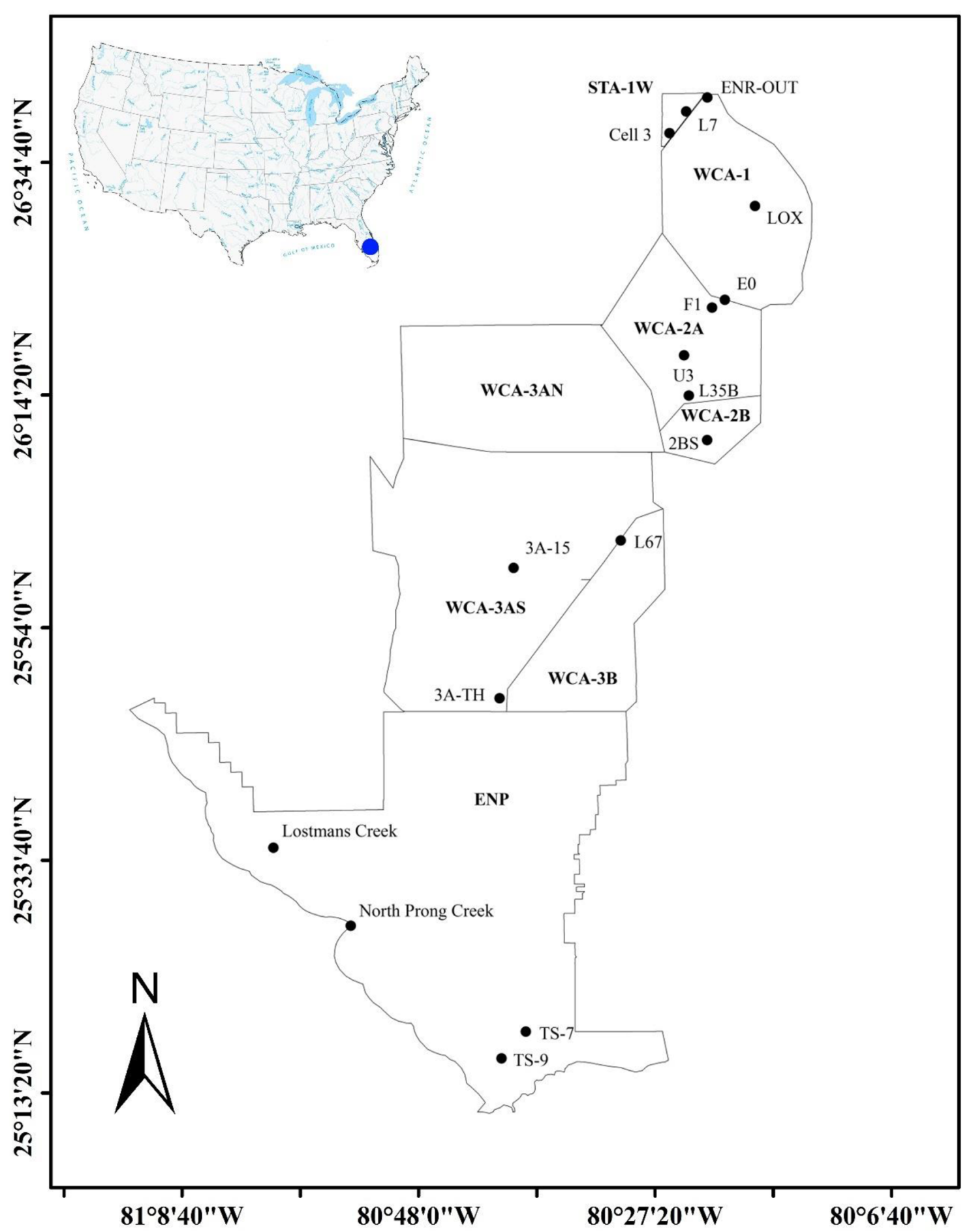

Fig. 1. Map showing sampling sites in Stormwater Management Area 1 West (STA-1W), Water Conservation Areas (WCAs) and Everglades National Park (ENP) of south Florida. The insert indicates location of the study site in the USA.

\section{Results}

\subsection{Environmental conditions}

The 16 study sites received water with considerably different concentrations of nutrients and other chemical compounds (Tab. 1). Study sites at Cell 3 and Cell 4 of the STA-1W, and E0 and F1 of WCA-2A, which received direct
EAA discharges are highly enriched with TP $\left(>40 \mu \mathrm{gL}^{-1}\right)$. Study sites located immediately downstream of STA-1W, WCAs or close to interior canals are moderately enriched with $\mathrm{TP}\left(>10\right.$ and $\left.<30 \mu \mathrm{g} \mathrm{L}^{-1}\right)$. Interior marshes in WCAs and ENP typically maintain the oligotrophic state indicated by a low TP concentration $\left(<10 \mu \mathrm{g} \mathrm{L}^{-1}\right)$. Total nitrogen $(\mathrm{TN})$ and dissolved inorganic nitrogen (DIN) concentrations were also higher at the near inflow sites than the marsh interior sites, except for 
J. Hong and B. Gu: Knowl. Manag. Aquat. Ecosyst. 2020, 421, 41

Table 1. Averages of environmental variables for each study site during the study period. Sites are generally listed from north to south.

\begin{tabular}{|c|c|c|c|c|c|c|c|c|}
\hline Site & $\begin{array}{l}\mathrm{pH} \\
\mathrm{SU}\end{array}$ & $\begin{array}{l}\text { DO } \\
\mathrm{mg} \mathrm{L}^{-1}\end{array}$ & $\begin{array}{l}\text { TP } \\
\mu \mathrm{g} \mathrm{L}^{-1}\end{array}$ & $\begin{array}{l}\text { SRP } \\
\mu \mathrm{g} \mathrm{L}^{-1}\end{array}$ & $\begin{array}{l}\mathrm{NH}_{4}^{+} \\
\mathrm{mg} \mathrm{L}^{-1}\end{array}$ & $\begin{array}{l}\mathrm{NO}_{\mathrm{x}}^{-} \\
\mathrm{mg} \mathrm{L}^{-1}\end{array}$ & $\begin{array}{l}\mathrm{TN} \\
\mathrm{mg} \mathrm{L}^{-1}\end{array}$ & $\begin{array}{l}\text { TN:TP } \\
\text { Molar ratio }\end{array}$ \\
\hline STA-W Cell 3* & 7.4 & 2.8 & 42 & 16 & 0.13 & 0.051 & 2.049 & 108 \\
\hline STA-W Cell $4^{*}$ & 7.1 & 1.5 & 46 & 12 & 0.169 & 0.026 & 2.071 & 99 \\
\hline ENR outflow ${ }^{*}$ & 7.4 & 3.6 & 24 & 8 & 0.047 & 0.061 & 2.271 & 206 \\
\hline L7 & 7.4 & 3.6 & 24 & 8 & 0.047 & 0.061 & 2.271 & 206 \\
\hline $\operatorname{LOX}^{*}$ & 6.4 & 3.1 & 8 & 1 & 0.023 & 0.007 & 1.208 & 322 \\
\hline E0 & 7.1 & 2.0 & 74 & 41 & 0.186 & 0.29 & 2.97 & 89 \\
\hline F1 & 7.2 & 1.7 & 70 & 24 & 0.575 & 0.061 & 2.861 & 91 \\
\hline $\mathrm{U}^{*}$ & 7.5 & 4.8 & 5 & 2 & 0.269 & 0.006 & 2.177 & 964 \\
\hline L35B & 7.2 & 4.1 & 13 & 5 & 0.017 & 0.038 & 1.748 & 298 \\
\hline 2BS & 7.3 & 3.9 & 21 & 4 & 0.049 & 0.058 & 1.541 & 162 \\
\hline $\mathrm{L} 67^{*}$ & 7.0 & 2.5 & 15 & 5 & 0.34 & 0.086 & 1.648 & 238 \\
\hline $3 \mathrm{~A} 15^{*}$ & 7.1 & 2.9 & 6 & 1 & 0.036 & 0.008 & 1.016 & 401 \\
\hline $3 \mathrm{ATH}$ & 7.2 & 3.6 & 13 & 4 & 0.032 & 0.063 & 1.377 & 242 \\
\hline TS-7 & 7.7 & 7.0 & 4 & 3 & 0.058 & 0.02 & 0.775 & 446 \\
\hline TS-9 & 7.7 & 7.0 & 4 & 3 & 0.058 & 0.02 & 0.775 & 446 \\
\hline North Prong Creek & 7.4 & 4.0 & 9 & 3 & 0.029 & 0.043 & 1.327 & 326 \\
\hline
\end{tabular}

Note: DO: dissolved oxygen. TP: total phosphorus. SRP: soluble reactive phosphorus; TN: total nitrogen. Averages are calculated from weekly to biweekly samples taken between 1990 and 1999.

Table 2. List of fish species and mean $\delta^{15} \mathrm{~N}$ ratios used in this analysis.

\begin{tabular}{|c|c|c|c|c|}
\hline Common name & Scientific name & Mean & SD & $\mathrm{N}$ \\
\hline Sailfin molly & Poecilia latipinna & 8.4 & 2.4 & 49 \\
\hline Golden topminnow & Fundulus chrysotus & 9.3 & 2.9 & 43 \\
\hline Mosquitofish & Gambusia holbrooki. & 10.6 & 2.8 & 473 \\
\hline Bluefin killifish & Lucania goodei & 10.6 & 2.8 & 72 \\
\hline Least killifish & Heterandria formosa & 10.8 & 3.0 & 171 \\
\hline Spotted sunfish & Lepomis punctatus & 9.3 & 1.1 & 81 \\
\hline Redear sunfish & Lepomis microlophus & 8.8 & 1.5 & 76 \\
\hline Bluegill & Lepomis macrochirus & 9.8 & 1.5 & 88 \\
\hline Largemouth bass & Micropterus salmoides & 11.1 & 1.5 & 576 \\
\hline Florida gar & Lepisosteus platyrhincus & 11.6 & 1.3 & 56 \\
\hline
\end{tabular}

$\mathrm{U} 3$, the interior site of WCA-2A, which is enriched with ammonium and TN. Theses study sites are also generally characterized by above-neutral $\mathrm{pH}$, high alkalinity, and low dissolved oxygen (DO) concentrations, with an exception of an interior site in WCA-1. This is a rain-driven system, where $\mathrm{pH}$ values are low (Tab. 1).

\subsection{Fish ecology and $\delta^{15} \mathrm{~N}$ ratios}

Species described in Table 2 represent major fish assemblage in the subtropical wetlands. They are either omnivorous, feeding on both algae, aquatic macrophytes and invertebrates (killifish, golden topminnow, mosquitofish and sailfin molly), primary consumers, feeding on aquatic insects (bluegill and spotted sunfish), snails (redear sunfish) or piscivores (largemouth bass and Florida gar).

Average $\delta^{15} \mathrm{~N}$ ratios for each species collected from multiple sites and years ranged from $8.4 \%$ in sailfin molly to $11.6 \%$ in Florida gar. In general, $\delta^{15} \mathrm{~N}$ ratios reflect the trophic position of each species. For example, both the Florida gar and largemouth bass which are piscivores displayed higher $\delta^{15} \mathrm{~N}$ ratios than all other species preying on lower trophic levels. Omnivorous species depending on both primary producers and invertebrates typically show low $\delta^{15} \mathrm{~N}$ ratios. It is surprising that the least killifish, bluefin killifish and mosquitofish which are reported depending partially on primary producers had higher $\delta^{15} \mathrm{~N}$ ratios than those reportedly true primary consumers such as the three sunfish species.

\subsection{Patterns of fish $\delta^{15} \mathrm{~N}$ along the nutrient gradient}

Fish $\delta^{15} \mathrm{~N}$ ratios selected in this analysis generally increased with the increases in TP concentrations (Figs. 2 and 3). Except for the golden topminnow, all other fish had significant correlation between water column TP concentrations and $\delta^{15} \mathrm{~N}$ ratios (Tab. 3). Significant correlation between TN concentrations and fish $\delta^{15} \mathrm{~N}$ ratios were found in five species (Tab. 3). Nearly all fish displayed a decline in $\delta^{15} \mathrm{~N}$ ratios with increases in molar TN/TP ratio although only seven species displayed significant correlation (Tab.3). Highly significant correlations $(p<0.001)$ between TP, TN, TN/TP ratio and $\delta{ }^{15} \mathrm{~N}$ ratios were found in the sailfin molly, 
J. Hong and B. Gu: Knowl. Manag. Aquat. Ecosyst. 2020, 421, 41

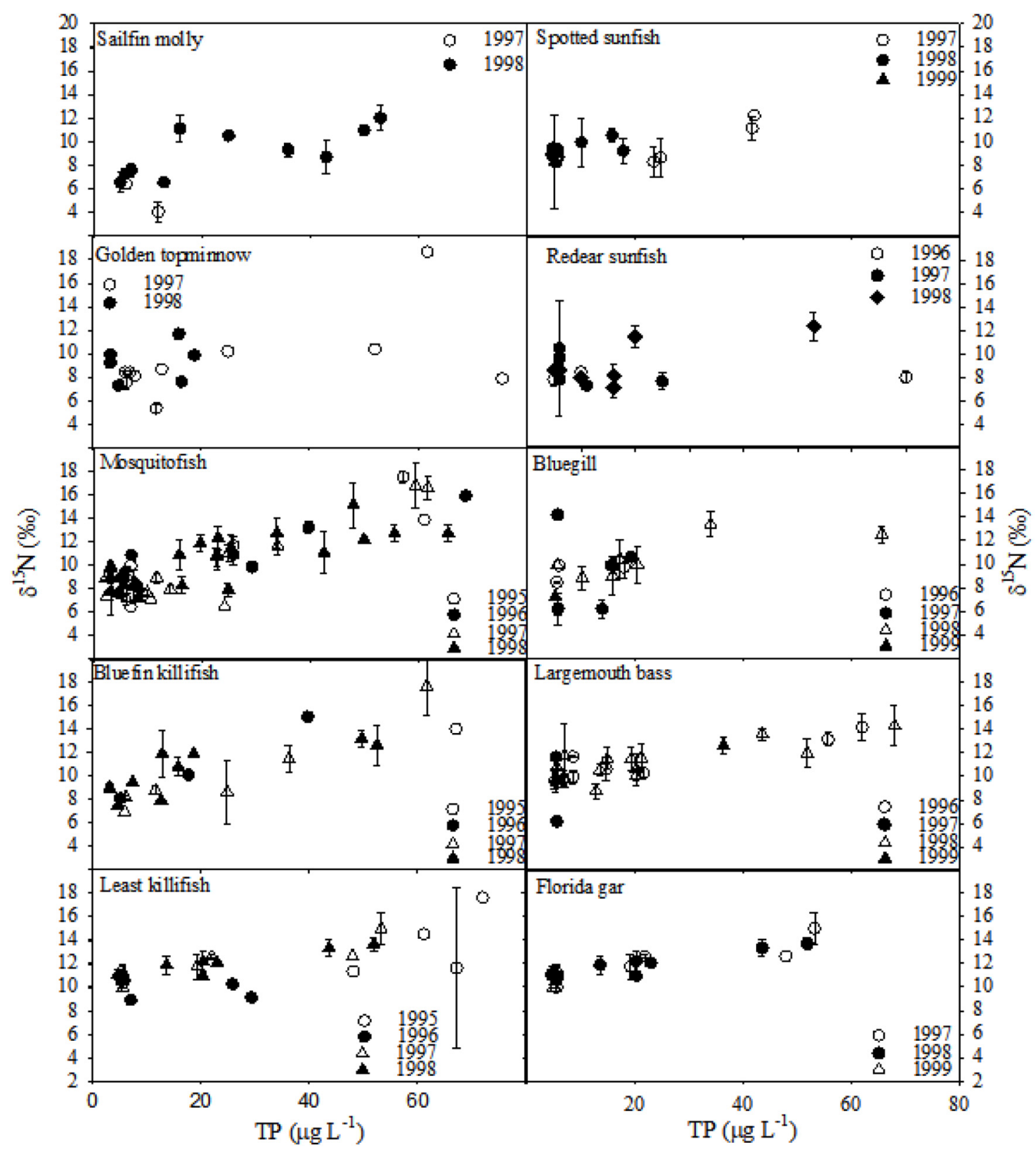

Fig. 2. $\delta^{15} \mathrm{~N}$ ratios (mean $\pm \mathrm{SD}$ ) of ten fish species along the TP concentration gradient in the Everglades wetlands. Each dot represents data from a specific date of sample collection in the 1990 s.

mosquitofish, least killifish, largemouth bass and Florida gar (Tab. 3). The $\delta^{15} \mathrm{~N}$ ratios of mosquitofish samples collected from seven study sites in 2007 were plotted against TP concentrations (Fig. 4). A highly significant relationship between nutrients and $\delta^{15} \mathrm{~N}$ ratios $(p<0.001)$ was also found in these samples.

The $\delta^{15} \mathrm{~N}$ ratios of mosquitofish and least killifish were available in all monitoring sites from WCA-2 (Fig. 1) and plotted along with TP concentrations collected for each site (Fig. 5). The $\delta^{15} \mathrm{~N}$ ratios of both fish and TP concentrations were considerably higher in both inflow (E0) and near inflow (F1) sites than those in the interior site (U3) of WCA-2A and near a canal site (L35B) and interior (2BS) WCA-2B which displayed similar $\delta^{15} \mathrm{~N}$ ratios but variously low TP concentrations.

\section{Discussion}

Findings from this analysis are consistent with previous studies, which reveal positive relationship between nutrient concentrations and biota $\delta^{15} \mathrm{~N}$ ratios (Cole et al., 2004; Inglett and Reddy, 2006; Gu et al., 2009). However, the results from this analysis may be complicated by several factors, including study design and variability of nutrient data selected for this analysis. For example, biological characteristics of fish including age, size, gender, growth rate and feeding habits at each site will certainly introduce additional variations. Without data for fish age and tissue turnover time, we used the average TP concentrations measured one year prior to fish collection, which may not accurately reflect the growth condition of fish. 
J. Hong and B. Gu: Knowl. Manag. Aquat. Ecosyst. 2020, 421, 41

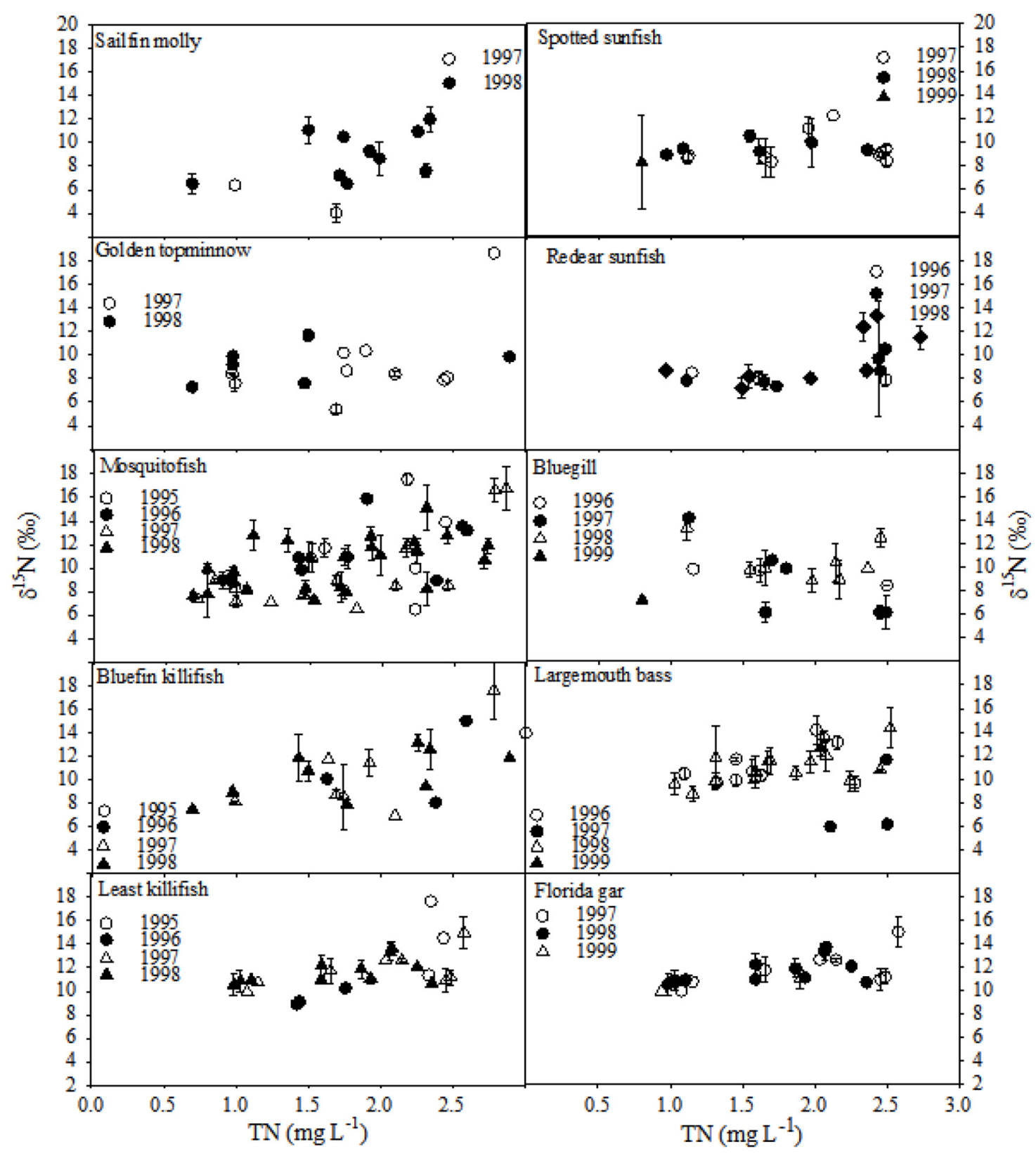

Fig. 3. $\delta^{15} \mathrm{~N}$ values (mean $\pm \mathrm{SD}$ ) of ten fish species along the TN concentration gradient in the Everglades wetlands. Each dot represents data from a specific date of sample collection in the 1990s.

Half of the species also had significant relationship between TN concentrations and $\delta^{15} \mathrm{~N}$ ratios. Nitrogen from human and animal wastes is often enriched in ${ }^{15} \mathrm{~N}$ (McClelland et al., 1997). Therefore, the increasing pattern of $\delta^{15} \mathrm{~N}$ ratios along the nutrient gradient may also be caused by increases in wastewater loading. Enriched $\delta^{15} \mathrm{~N}$ of various flora and fauna has been used as an indicator for sewage influence in the freshwater and coastal marine environments (Cole et al., 2004; Rožič et al., 2014; Souza et al., 2018; de Carvalho et al., 2019). There have been no reports of any significant wastewater contributions from human or animal sources to the Everglades. Inglett et al. (2005) reported that the $\delta^{15} \mathrm{~N}$ ratios of porewater $\mathrm{NH}_{4}{ }^{+}$(the dominant $\mathrm{N}$ species in reduced soils) is similar at both the eutrophic and nonaffected WCA-2A sites. The high $\delta^{15} \mathrm{~N}$ at the impacted sites is unlikely the result of the uptake of wastewater enriched with ${ }^{15} \mathrm{~N}$ and subsequent transfers to the consumer community (Cabana and Rasmussen, 1995).

Other nitrogen cycling processes (nitrification, denitrification and volatilization) may impact on the isotope composition of DIN in natural wetlands. However, ammonium, not nitrate, was the dominant species of DIN in this region (Tab. 1). Under low DO concentrations in this shallow wetland, nitrification is not likely the main process. Denitrification occurs under low DO concentrations and may result in significant changes in isotope composition the substate and products. However, nitrate was not the major form of DIN in the Everglades. Finally, volatilization occurs only under high $\mathrm{pH}$ and the nearly neutral $\mathrm{pH}$ found in the south Florida wetlands (Tab. 1) makes this process highly unlikely. Along with the findings from a previous study showing the similar $\mathrm{N}$ signatures in both 
Table 3. Result of Spearman Rank Correlation between fish $\delta^{15} \mathrm{~N}$ ratios, water-column TP and TN concentrations and molar TN/TP ratios in this study.

\begin{tabular}{|c|c|c|c|c|}
\hline Species name & $\mathrm{TP}$ & $\mathrm{TN}$ & TN:TP & $\mathrm{N}$ \\
\hline Sailfin molly & $0.76^{* * *}$ & 0.55 & $-0.50^{* *}$ & 12 \\
\hline Golden topminnow & 0.46 & 0.29 & -0.31 & 16 \\
\hline Mosquitofish & $0.76^{* * *}$ & $0.55^{* * *}$ & $-0.72^{* * *}$ & 56 \\
\hline Bluefin killifish & $0.77^{* * *}$ & $0.50^{*}$ & $-0.72^{* * *}$ & 21 \\
\hline Least killifish & $0.72^{* * *}$ & $0.64^{* * *}$ & $-0.73^{* * *}$ & 33 \\
\hline Spotted sunfish & $0.69^{* * *}$ & 0.23 & -0.12 & 17 \\
\hline Redear sunfish & $0.52^{*}$ & 0.44 & 0.17 & 16 \\
\hline Bluegill & $0.53^{*}$ & 0.38 & $-0.51^{*}$ & 21 \\
\hline Largemouth bass & $0.69^{* * *}$ & $0.46^{* * *}$ & $-0.57^{* * *}$ & 40 \\
\hline Florida gar & $0.80^{* * *}$ & $0.63^{* * *}$ & $-0.64^{* * *}$ & 21 \\
\hline
\end{tabular}

$* p<0.05 ; * * p<0.01 ; * * * p<0.001$.

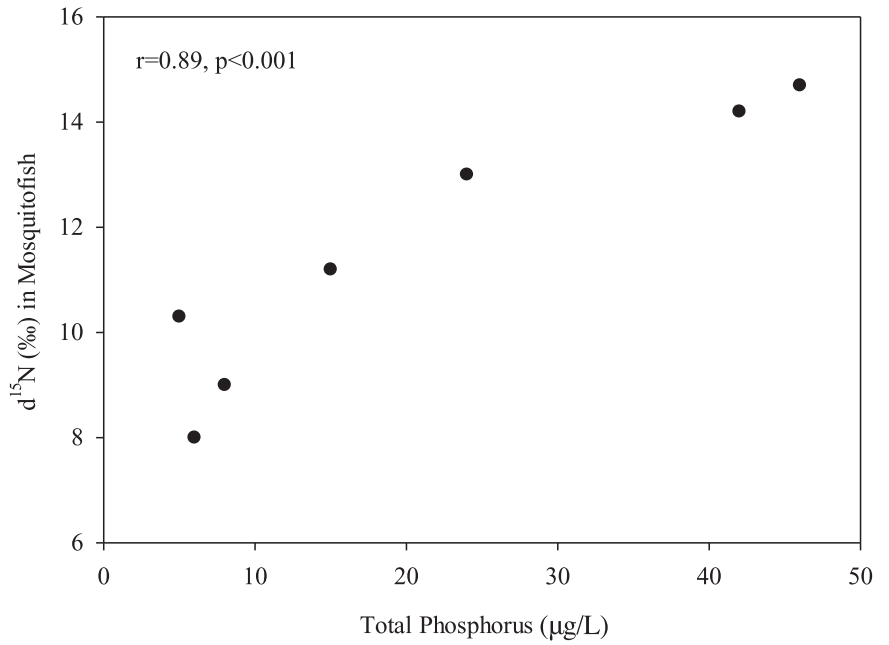

Fig. 4. Relationship between total $\mathrm{P}(\mathrm{TP})$ concentration and $\delta^{15} \mathrm{~N}$ ratios in mosquitofish collected from the Everglades Protection Area in 2007 .

affected and unaffected area of Everglades (Inglett et al., 2006), site-specific $\mathrm{N}$ transformation would not likely be the major process leading to the differences in fish $\delta^{15} \mathrm{~N}$.

Nitrogen concentration may also influence biota $\delta^{15} \mathrm{~N}$ ratios through a substrate-mediated isotope effect (Peterson and Fry, 1987). When $\mathrm{N}$ is not a limiting nutrient in a system, an increase in $\mathrm{N}$ concentration will normally cause an increase in isotopic fractionation and therefore a decrease in $\delta^{15} \mathrm{~N}$ ratios. This would be evidenced by a negative correlation between TN concentration and fish $\delta^{15} \mathrm{~N}$ ratios in this study. Instead, the majority of the fish in this study displayed positive relationship between TN and $\delta^{15} \mathrm{~N}$ ratios. This implies that $\mathrm{N}$ is not a limiting nutrient to plant growth in the Everglades. This is also supported by the high molar ratios of TN:TP ratios. Some negative correlation between the water column TN:TP ratio and the fish $\delta^{15} \mathrm{~N}$ ratios also indicate that $\mathrm{P}$, not $\mathrm{N}$, is the limiting nutrient in the Everglades.

The major external source of $\mathrm{N}$ in the Everglades is agricultural runoff (Richardson, 2010). Because manufactured fertilizers are depleted in ${ }^{15} \mathrm{~N}$ (Kohl et al., 1971), assimilation of this ${ }^{15} \mathrm{~N}$-depleted $\mathrm{N}$ will not result in ${ }^{15} \mathrm{~N}$ enrichment in the impacted sites. We conclude that the ${ }^{15} \mathrm{~N}$ enrichment in the

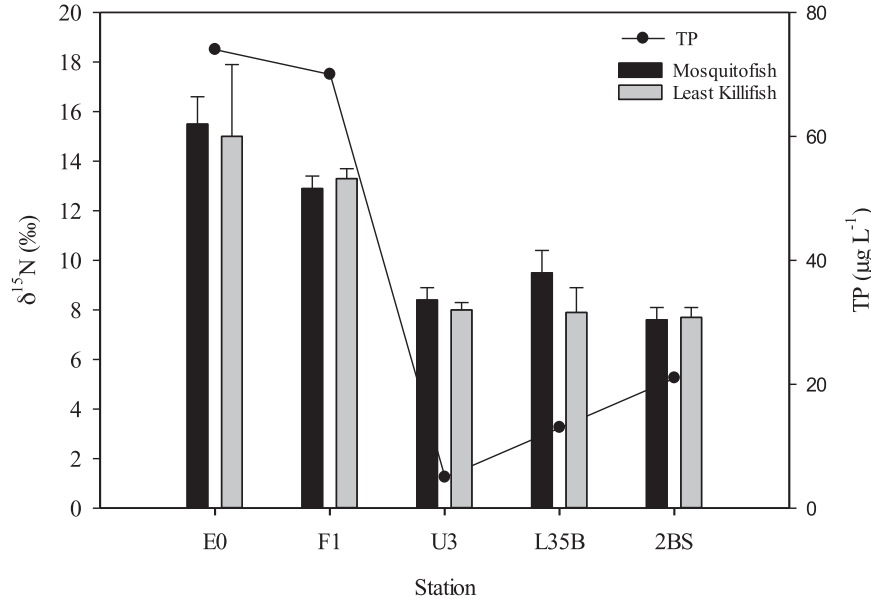

Fig. 5. Changes in the $\delta^{15} \mathrm{~N}$ ratios of mosquitofish and least killifish and TP concentrations along the nutrient gradient in the WCA-2.

Everglades is the result of increased primary production stimulated by $\mathrm{P}$ availability. The average $\delta^{15} \mathrm{~N}$ ratios for fish increase progressively along the TP gradient. The low $\delta^{15} \mathrm{~N}$ ratios in fish at the unimpacted sites was the result of low TP concentration and large ${ }^{15} \mathrm{~N}$ fractionation by primary producers during DIN uptake under $\mathrm{P}$ stress. The high $\mathrm{N}$ availability at the unimpacted sites also allowed selective assimilation of ${ }^{14} \mathrm{~N}$ by aquatic plants. In contrast, the high $\delta^{15} \mathrm{~N}$ ratios at the impacted sites were due to $\mathrm{P}$ enrichment which leads to high $\mathrm{N}$ demand and low ${ }^{15} \mathrm{~N}$ fractionation. Many studies have demonstrated that $\mathrm{P}$ is the limiting nutrient in the Everglades (e.g., Newman et al., 1996). Recent studies using stable isotopes found a positive relationship between the TP and $\delta{ }^{15} \mathrm{~N}$ ratios of periphyton, sawgrass and cattail in WCA-1 and WCA-2A, which was attributed to P-driven plant growth and reduced isotope fractionation (Inglett and Reddy, 2006; Chang et al., 2009; Wang et al., 2015).

The widespread significant correlation between TP concentrations and fish $\delta^{15} \mathrm{~N}$ ratios is the consequence of the transfers of plant protein and the associated ${ }^{15} \mathrm{~N} /{ }^{14} \mathrm{~N}$ signal to the consumers, with ${ }^{15} \mathrm{~N}$ enrichment along the food chain. The consumer $\delta^{15} \mathrm{~N}$ ratios increases along the TP gradient, which is consistent with the pattern of increases in the primary 
producers. Furthermore, the relationship between TP concentration and fish $\delta^{15} \mathrm{~N}$ ratios seems to improve as the trophic level increases. For example, Florida gar, which is positioned at the highest trophic level in our samples, had the highest correlation coefficient $(r=0.80)$ with a moderate sample size $(n=21)$ among fish selected for this study. In general, fish $\delta^{15} \mathrm{~N}$ is a better indicator of the eutrophication process because they integrate temporal and spatial variations in source $\delta^{15} \mathrm{~N}$ ratios over longer time periods (Cabana and Rasmussen, 1996; Vander Zanden et al., 2005).

\section{Conclusions}

The eutrophication process resulting from excessive $\mathrm{P}$ loading from the agricultural runoff to the Everglades is demonstrated using the nitrogen stable isotopic ratios of fish. The $\delta^{15} \mathrm{~N}$ ratios of nearly all fish species responded positively to the increases in TP concentration. This is considered to be caused by increasing the $\mathrm{N}$ uptake and decreasing the ${ }^{15} \mathrm{~N}$ fractionation by primary producers stimulated by $\mathrm{P}$ enrichment. The ${ }^{15} \mathrm{~N}$ enrichment along the nutrient gradient is evident in fish that reliably transfer the isotope signals from primary producers along the trophic level. The significant correlations between TP concentration and $\delta^{15} \mathrm{~N}$ ratios in mosquitofish in the 1990s and 2007 suggest that the eutrophication trend along the nutrient gradient persisted after almost two decades. Results from this study indicate that aquatic consumers such as fish are the better environmental indicators because they are capable of integrating biogeochemical changes over time.

\section{Compliance with ethical standards}

Conflict of interest: On behalf of all authors, the corresponding author states that there is no conflict of interest.

Acknowledgements. We appreciate the United States Geological Survey and South Florida Water Management District for providing stable isotope and water quality data.

\section{References}

Cabana G, Rasmussen JB. 1996. Comparison of Aquatic Food Chains Using Nitrogen Isotopes. Proc Natl Acad Sci USA. 93: 10844-10847.

Chang CCY, McCormick PV, Newman S. 2009. Isotopic indicators of environmental change in a subtropical wetland. Ecol Indic 9: 825-836.

Cole ML, Valiela I, Kroeger KD. 2004. Assessment of a $\delta^{15} \mathrm{~N}$ isotopic method to indicate anthropogenic eutrophication in aquatic ecosystems. J Environ Qual 33: 124-132.

de Carvalho DR, Flecker AS, Alves CBM, Sparks JP, Pompeu PS. 2019. Trophic responses to aquatic pollution of native and exotic livebearer fishes. Sci. Total Environ 681: 503-515.
$\mathrm{Gu}$ B. 2009. Variations and controls of nitrogen stable isotopes in particulate organic matter of lakes. Oecologia 160: 421-431.

Hou W, Gu B, Zhang H, Gu J, Han BP. 2013. The relationship between carbon and nitrogen stable isotopes of zooplankton and select environmental variables in low-latitude reservoirs. Limnology 14:97-104.

Inglett PW, Reddy KR. 2006. Investigating the use of macrophyte stable $\mathrm{C}$ and $\mathrm{N}$ isotopic ratios as indicators of wetland eutrophication: patterns in the P-affected Everglades. Limnol Oceanogr 51: 2380-2387.

Jeppesen E, Sammalkorpi 2002. 13 - Lakes. Handbook of Ecological Restoration, 2, 297. Perrow MR, Davy AJ (Eds.). Cambridge University Press.

Kendall C, Silva S, Steinitz D, Wise E, Chang C. 2005. Mapping Spatial Variability in Marsh Redox Conditions Using Biomass Stable Isotopic Compositions. In: https://inis.iaea.org/collection/ NCLCollectionStore/_Public/30/025/30025838.pdf

Kohl DH, Shearer GB, Commoner B. 1971. Fertilizer nitrogen: contribution to nitrate in surface water in a corn belt watershed. Science 174: 1331.

Lake JL, McKinney RA, Osterman FA. 2001. Stable nitrogen isotopes as indicators of anthropogenic activities in small freshwater systems. Can J Fish Aquat Sci 58: 870-878.

McClelland JW, Valiela I, Michener RH. 1997. Nitrogen-stable isotope signatures in estuarine food webs: A record of increasing urbanization in coastal watersheds. Limnol Oceanogr 42: 930-937.

Newman S, Grace JB, Koebel JW. 1996. Effects of nutrients and hydroperiod on Typha, Cladium, and Eleocharis: implications for Everglades restoration. Ecol Appl 6: 774-783.

Peterson BJ, Fry B. 1987. Stable isotopes in ecosystem studies. Annu Rev Ecol Syst 18: 293-320.

Post DM. 2002. Using stable isotopes to estimate trophic position: models, methods, and assumptions. Ecology 83: 703-718.

Richardson CJ. 2010. The everglades: North America's subtropical wetland. Wetl Ecol Manag 18: 517-542.

Robinson CS, Tetreault, GR, McMaster, ME, Servos MR. 2016. Impacts of a tertiary treated municipal wastewater effluent on the carbon and nitrogen stable isotope signatures of two darter species (Etheostoma blennioides and E. caeruleum) in a small receiving environment. Ecol Indic 60: 594-602.

Rožič PŽ, Dolenec T, Lojen S, Kniewald G, Dolenec M. 2014. Using stable nitrogen isotopes in Patella sp. to trace sewage-derived material in coastal ecosystems. Ecol Ind 36: 224-230.

Schlacher TA, Liddell B, Gaston, TF, Schlacher-Hoenlinger M. 2005. Fish track wastewater pollution to estuaries. Oecologia 144: $570-584$.

Sklar FH, Chimney MJ, Newman S et al. 2005. The ecologicalsocietal underpinnings of Everglades restoration. Front Ecol Environ 3: 161-169.

Souza IDC, Arrivabene HP, Craig CA, Midwood AJ, Thornton B, Matsumoto ST, Elliott M, Wunderlin DA, Monferrán MV, Fernandes MN. 2018. Interrogating pollution sources in a mangrove food web using multiple stable isotopes. Sci Total Environ 640: 501-511.

Vander Zanden MJ, Vadeboncoeur Y, Diebel MW, Jeppesen E. 2005. Primary consumer stable nitrogen isotopes as indicators of nutrient source. Environ Sci Tech 39: 7509-7515.

Vander Zanden MJ, Clayton MK, Moody EK, Solomon CT, Weidel BC. 2015. Stable isotope turnover and half-life in animal tissues: a literature synthesis. PloS one, 10: p.e0116182. 
Wang J, Gu B, Ewe SM, Wang Y, Li Y. 2015. Stable isotope compositions of aquatic flora as indicators of wetland eutrophication. Ecol Eng 83:13-18.

Wang J, Chapman D, Xu J, Wang Y, Gu B. 2018. Isotope niche dimension and trophic overlap between bigheaded carps and native filter-feeding fish in the lower Missouri River, USA. PloS one, 13: e0197584.
Woodland RJ, Magnan P, Glémet H, et al. 2012. Variability and directionality of temporal changes in $\delta 13 \mathrm{C}$ and $\delta 15 \mathrm{~N}$ of aquatic invertebrate primary consumers. Oecologia 169: 199-209.

Wright AL, Reddy KR, Newman S. 2008. Biogeochemical response of the Everglades landscape to eutrophication. Int J Environ Res 2: $102-109$.

Cite this article as: Hong J, Gu B. 2020. Responses of nitrogen stable isotopes in fish to phosphorus limitation in freshwater wetlands. Knowl. Manag. Aquat. Ecosyst., 421, 41. 


\section{Appendix}

Table A1. Stable isotope data used in this analysis.

\begin{tabular}{|c|c|c|c|c|c|}
\hline $\begin{array}{l}\text { 1. Data from 1990s } \\
\text { Site }\end{array}$ & DATE & Common Name & $\delta^{15} \mathrm{~N}$ mean & $\delta^{15} \mathrm{~N}$ SD & $\mathrm{N}$ \\
\hline TS-7 & Jan-1998 & Golden Topminnow & 9.92 & 0.26 & 4 \\
\hline TS-9 & Jan-1998 & Golden Topminnow & 9.22 & 0.45 & 3 \\
\hline $3 \mathrm{~A} 15$ & Jan-1998 & Golden Topminnow & 7.29 & 0.27 & 7 \\
\hline U3 & Sep-1997 & Golden Topminnow & 8.39 & 0.19 & 3 \\
\hline $3 \mathrm{~A} 15$ & Sep-1997 & Golden Topminnow & 7.58 & 0.65 & 2 \\
\hline 3A15 & Jun-1998 & Golden Topminnow & 8.40 & 0.12 & 2 \\
\hline U3 & Jul-1997 & Golden Topminnow & 8.10 & & 1 \\
\hline L35B & Sep-1997 & Golden Topminnow & 5.36 & 0.36 & 3 \\
\hline 2BS & Jul-1997 & Golden Topminnow & 8.68 & & 1 \\
\hline L67 & Jan-1998 & Golden Topminnow & 11.68 & 0.46 & 3 \\
\hline 2BS & Jan-1998 & Golden Topminnow & 7.61 & 0.42 & 9 \\
\hline ENR-OUT & Jan-1998 & Golden Topminnow & 9.86 & & 1 \\
\hline L67 & Sep-1997 & Golden Topminnow & 10.20 & & 1 \\
\hline Cell 3 & Jun-1997 & Golden Topminnow & 10.38 & & 1 \\
\hline E0 & Jul-1997 & Golden Topminnow & 18.66 & & 1 \\
\hline $\mathrm{F} 1$ & Sep-1997 & Golden Topminnow & 7.87 & & 1 \\
\hline $3 \mathrm{~A} 15$ & Jan-1998 & Sailfin Molly & 6.52 & 0.85 & 4 \\
\hline U3 & Jun-1998 & Sailfin Molly & 7.23 & 0.46 & 4 \\
\hline $3 \mathrm{~A} 15$ & Sep-1997 & Sailfin Molly & 6.39 & & 1 \\
\hline L35B & Jan-1998 & Sailfin Molly & 7.59 & 0.56 & 2 \\
\hline L35B & Sep-1997 & Sailfin Molly & 4.02 & 0.84 & 4 \\
\hline 2BS & Jan-1998 & Sailfin Molly & 6.52 & 0.34 & 5 \\
\hline L67 & Jan-1998 & Sailfin Molly & 11.08 & 1.10 & 5 \\
\hline L67 & Jun-1998 & Sailfin Molly & 10.49 & & 1 \\
\hline Cell 3 & Jun-1997 & Sailfin Molly & 9.28 & 0.55 & 6 \\
\hline Cell 4 & Jun-1998 & Sailfin Molly & 8.66 & 1.37 & 7 \\
\hline Cell 3 & Jun-1998 & Sailfin Molly & 10.95 & 0.19 & 6 \\
\hline Cell 3 & Jan-1998 & Sailfin Molly & 11.99 & 1.09 & 4 \\
\hline Cell 3 & Jun-1997 & Least Killifish & 11.04 & 0.62 & 12 \\
\hline Cell 3 & Jan-1998 & Least Killifish & 13.44 & 0.54 & 9 \\
\hline Cell 3 & Jun-1998 & Least Killifish & 13.02 & 0.59 & 10 \\
\hline LOX & Jan-1998 & Least Killifish & 8.63 & 0.34 & 5 \\
\hline E0 & Dec-1995 & Least Killifish & 11.66 & 6.89 & 2 \\
\hline E0 & Jul-1995 & Least Killifish & 14.51 & & 1 \\
\hline E0 & Jun-1998 & Least Killifish & 15.97 & 0.62 & 9 \\
\hline E0 & Sep-1997 & Least Killifish & 16.77 & 1.57 & 5 \\
\hline $\mathrm{F} 1$ & Mar-1995 & Least Killifish & 17.64 & & 1 \\
\hline $\mathrm{F} 1$ & Jul-1995 & Least Killifish & 11.35 & & 1 \\
\hline $\mathrm{F} 1$ & Jun-1996 & Least Killifish & 15.54 & & 1 \\
\hline $\mathrm{F} 1$ & Dec-1996 & Least Killifish & 13.71 & 0.57 & 2 \\
\hline F1 & Sep-1997 & Least Killifish & 11.01 & 0.33 & 4 \\
\hline $\mathrm{F} 1$ & Jan-1998 & Least Killifish & 12.64 & 0.47 & 6 \\
\hline U3 & Jul-1997 & Least Killifish & 8.43 & 0.06 & 2 \\
\hline U3 & Sep-1997 & Least Killifish & 8.27 & 0.60 & 2 \\
\hline L35B & Sep-1997 & Least Killifish & 6.71 & 1.07 & 5 \\
\hline $2 \mathrm{BS}$ & Jan-1998 & Least Killifish & 7.68 & 0.47 & 11 \\
\hline L67 & Jun-1996 & Least Killifish & 9.10 & & 1 \\
\hline L67 & Dec-1996 & Least Killifish & 10.25 & & 1 \\
\hline L67 & Sep-1997 & Least Killifish & 12.57 & & 1 \\
\hline
\end{tabular}


Table A1. (continued).

\begin{tabular}{|c|c|c|c|c|c|}
\hline $\begin{array}{l}\text { 1. Data from 1990s } \\
\text { Site }\end{array}$ & DATE & Common Name & $\delta^{15} \mathrm{~N}$ mean & $\delta^{15} \mathrm{~N} \mathrm{SD}$ & $\mathrm{N}$ \\
\hline L67 & Jan-1998 & Least Killifish & 12.28 & 0.93 & 8 \\
\hline L67 & Jun-1998 & Least Killifish & 12.00 & 2.03 & 8 \\
\hline $3 \mathrm{~A} 15$ & Jun-1996 & Least Killifish & 8.90 & & 1 \\
\hline $3 \mathrm{~A} 15$ & Jul-1997 & Least Killifish & 8.39 & 0.55 & 3 \\
\hline $3 \mathrm{~A} 15$ & Sep-1997 & Least Killifish & 7.88 & 0.54 & 5 \\
\hline $3 \mathrm{~A} 15$ & Jan-1998 & Least Killifish & 7.98 & 0.33 & 15 \\
\hline $3 \mathrm{~A} 15$ & Jun-1998 & Least Killifish & 7.80 & 0.43 & 12 \\
\hline 3A-Th & Sep-1997 & Least Killifish & 7.38 & 0.33 & 3 \\
\hline 3A-Th & Jan-1998 & Least Killifish & 7.87 & 0.37 & 15 \\
\hline TS-7 & Jan-1998 & Least Killifish & 9.49 & 1.04 & 2 \\
\hline TS-9 & Jan-1998 & Least Killifish & 9.63 & 0.30 & 4 \\
\hline TS-9 & Jun-1998 & Least Killifish & 8.30 & 0.56 & 4 \\
\hline 2BS & Jul-1997 & Mosquitofish & 7.95 & 0.35 & 5 \\
\hline 2BS & Jan-1998 & Mosquitofish & 8.30 & 0.69 & 11 \\
\hline $2 \mathrm{BS}$ & Apr-1997 & Mosquitofish & 6.53 & & 1 \\
\hline 2BS & Jun-1998 & Mosquitofish & 7.93 & 0.54 & 12 \\
\hline $3 \mathrm{~A} 15$ & Jan-1998 & Mosquitofish & 7.64 & 0.38 & 14 \\
\hline $3 \mathrm{~A} 15$ & Dec-1996 & Mosquitofish & 8.97 & 0.68 & 5 \\
\hline $3 \mathrm{~A} 15$ & Jul-1997 & Mosquitofish & 8.31 & 1.40 & 5 \\
\hline $3 \mathrm{~A} 15$ & Sep-1997 & Mosquitofish & 7.16 & 0.52 & 5 \\
\hline $3 \mathrm{~A} 15$ & Apr-1997 & Mosquitofish & 9.05 & 0.81 & 9 \\
\hline $3 \mathrm{~A} 15$ & Jun-1996 & Mosquitofish & 10.86 & & 1 \\
\hline 3A-Th & Jan-1998 & Mosquitofish & 7.28 & 0.25 & 15 \\
\hline $3 \mathrm{~A}-\mathrm{Th}$ & Sep-1997 & Mosquitofish & 7.69 & 0.19 & 5 \\
\hline 3A-Th & Jul-1997 & Mosquitofish & 7.12 & & 1 \\
\hline Cell 3 & Jun-1998 & Mosquitofish & 12.77 & 1.27 & 20 \\
\hline Cell 3 & Jun-1997 & Mosquitofish & 11.68 & 0.77 & 21 \\
\hline Cell 3 & Jan-1998 & Mosquitofish & 12.73 & 0.71 & 15 \\
\hline Cell 4 & Jun-1998 & Mosquitofish & 11.09 & 1.75 & 8 \\
\hline E0 & Dec-1996 & Mosquitofish & 13.20 & 0.48 & 5 \\
\hline E0 & Jun-1998 & Mosquitofish & 15.12 & 1.92 & 18 \\
\hline E0 & Mar-1995 & Mosquitofish & 17.52 & 0.51 & 2 \\
\hline E0 & Sep-1997 & Mosquitofish & 16.77 & 1.90 & 5 \\
\hline E0 & Jul-1995 & Mosquitofish & 13.89 & & 1 \\
\hline E0 & Jul-1997 & Mosquitofish & 16.61 & 1.03 & 5 \\
\hline E0 & Jun-1996 & Mosquitofish & 15.89 & & 1 \\
\hline ENR-OUT & Jan-1998 & Mosquitofish & 11.89 & 0.67 & 9 \\
\hline ENR-OUT & Jun-1998 & Mosquitofish & 10.71 & 0.76 & 9 \\
\hline $\mathrm{F} 1$ & Feb-1998 & Mosquitofish & 12.20 & & 1 \\
\hline $\mathrm{F} 1$ & Jun-1998 & Mosquitofish & 12.71 & 0.74 & 14 \\
\hline $\mathrm{F} 1$ & Dec-1996 & Mosquitofish & 13.55 & 0.11 & 2 \\
\hline $\mathrm{F} 1$ & Jun-1996 & Mosquitofish & 16.64 & & 1 \\
\hline $\mathrm{F} 1$ & Sep-1997 & Mosquitofish & 11.94 & 0.35 & 5 \\
\hline F1 & Jan-1998 & Mosquitofish & 11.77 & 1.09 & 10 \\
\hline $\mathrm{F} 1$ & Jul-1995 & Mosquitofish & 11.62 & & 1 \\
\hline L35B & Jan-1998 & Mosquitofish & 8.22 & 1.44 & 19 \\
\hline L35B & Sep-1997 & Mosquitofish & 8.96 & 0.43 & 4 \\
\hline L35B & Jun-1998 & Mosquitofish & 11.45 & 1.08 & 20 \\
\hline L67 & Jan-1998 & Mosquitofish & 10.91 & 1.25 & 20 \\
\hline L67 & Jul-1997 & Mosquitofish & 10.88 & 1.25 & 8 \\
\hline L67 & Jun-1998 & Mosquitofish & 12.35 & 0.98 & 40 \\
\hline L67 & Sep-1997 & Mosquitofish & 10.98 & 0.72 & 10 \\
\hline
\end{tabular}


Table A1. (continued).

\begin{tabular}{|c|c|c|c|c|c|}
\hline $\begin{array}{l}\text { 1. Data from } 1990 \mathrm{~s} \\
\text { Site }\end{array}$ & DATE & Common Name & $\delta^{15} \mathrm{~N}$ mean & $\delta^{15} \mathrm{~N}$ SD & $\mathrm{N}$ \\
\hline L67 & Jul-1995 & Mosquitofish & 11.68 & 0.76 & 4 \\
\hline L67 & Dec-1996 & Mosquitofish & 10.92 & 0.96 & 12 \\
\hline L67 & Jun-1996 & Mosquitofish & 9.86 & & 2 \\
\hline LOX & Jan-1998 & Mosquitofish & 8.18 & 0.35 & 6 \\
\hline TS-7 & Jul-1997 & Mosquitofish & 8.92 & 0.13 & 2 \\
\hline TS-7 & Jan-1998 & Mosquitofish & 9.71 & 0.36 & 10 \\
\hline TS-7 & Jun-1998 & Mosquitofish & 9.94 & 0.41 & 10 \\
\hline TS-9 & Jul-1997 & Mosquitofish & 7.35 & & 1 \\
\hline TS-9 & Jan-1998 & Mosquitofish & 8.88 & 0.46 & 20 \\
\hline TS-9 & Jun-1998 & Mosquitofish & 7.78 & 1.95 & 16 \\
\hline U3 & Dec-1996 & Mosquitofish & 8.93 & 0.15 & 2 \\
\hline U3 & Jun-1998 & Mosquitofish & 8.40 & 1.29 & 13 \\
\hline U3 & Sep-1997 & Mosquitofish & 8.48 & 0.33 & 5 \\
\hline U3 & Mar-1995 & Mosquitofish & 9.98 & & 1 \\
\hline U3 & Jul-1995 & Mosquitofish & 6.49 & & 1 \\
\hline U3 & Jul-1997 & Mosquitofish & 8.50 & 0.40 & 5 \\
\hline Cell 3 & Jun-1997 & Bluefin Killifish & 11.41 & 1.16 & 12 \\
\hline Cell 3 & Jan-1998 & Bluefin Killifish & 12.60 & 1.72 & 4 \\
\hline Cell 3 & Jun-1998 & Bluefin Killifish & 13.14 & 0.71 & 5 \\
\hline ENR-OUT & Jan-1998 & Bluefin Killifish & 11.83 & 0.00 & 2 \\
\hline E0 & Dec-1995 & Bluefin Killifish & 13.97 & & 1 \\
\hline E0 & Dec-1996 & Bluefin Killifish & 15.00 & & 1 \\
\hline E0 & Sep-1997 & Bluefin Killifish & 17.61 & 2.47 & 7 \\
\hline F1 & Sep-1997 & Bluefin Killifish & 11.74 & & 1 \\
\hline U3 & Dec-1996 & Bluefin Killifish & 8.06 & & 1 \\
\hline U3 & Sep-1997 & Bluefin Killifish & 6.93 & & 1 \\
\hline L35B & Sep-1997 & Bluefin Killifish & 8.76 & 0.35 & 3 \\
\hline L35B & Jan-1998 & Bluefin Killifish & 9.45 & & 1 \\
\hline 2BS & Jan-1998 & Bluefin Killifish & 7.90 & & 1 \\
\hline L67 & Jun-1996 & Bluefin Killifish & 10.06 & & 1 \\
\hline L67 & Sep-1997 & Bluefin Killifish & 8.59 & 2.77 & 3 \\
\hline L67 & Jan-1998 & Bluefin Killifish & 10.77 & 0.83 & 8 \\
\hline L67 & Jun-1998 & Bluefin Killifish & 11.87 & 2.04 & 6 \\
\hline $3 \mathrm{~A} 15$ & Sep-1997 & Bluefin Killifish & 8.14 & 0.10 & 2 \\
\hline $3 \mathrm{~A} 15$ & Jan-1998 & Bluefin Killifish & 7.47 & 0.11 & 5 \\
\hline TS-7 & Jan-1998 & Bluefin Killifish & 8.85 & 0.26 & 2 \\
\hline TS-9 & Jan-1998 & Bluefin Killifish & 8.98 & 0.38 & 5 \\
\hline Cell 3 & Apr-1997 & Spotted Sunfish & 11.12 & 0.97 & 6 \\
\hline Cell 3 & Oct-1997 & Spotted Sunfish & 12.21 & & 1 \\
\hline $\mathrm{U} 3$ & Oct-1996 & Spotted Sunfish & 8.36 & 0.47 & 5 \\
\hline U3 & Sep-1997 & Spotted Sunfish & 8.86 & 0.24 & 5 \\
\hline U3 & Oct-1997 & Spotted Sunfish & 9.36 & 0.28 & 2 \\
\hline U3 & Nov-1997 & Spotted Sunfish & 9.09 & & 1 \\
\hline U3 & Jan-1998 & Spotted Sunfish & 9.29 & 0.42 & 3 \\
\hline L35B & Oct-1996 & Spotted Sunfish & 9.18 & 1.12 & 15 \\
\hline L35B & Jan-1998 & Spotted Sunfish & 9.90 & 2.03 & 14 \\
\hline L67 & Feb-1997 & Spotted Sunfish & 8.60 & 1.67 & 4 \\
\hline L67 & Jun-1997 & Spotted Sunfish & 8.28 & 1.25 & 3 \\
\hline L67 & Jan-1998 & Spotted Sunfish & 10.51 & 0.52 & 4 \\
\hline $3 \mathrm{~A} 15$ & Sep-1997 & Spotted Sunfish & 8.62 & 0.56 & 5 \\
\hline $3 \mathrm{~A} 15$ & Oct-1997 & Spotted Sunfish & 8.80 & 0.48 & 5 \\
\hline $3 \mathrm{~A} 15$ & Jan-1998 & Spotted Sunfish & 9.42 & 0.45 & 4 \\
\hline
\end{tabular}


Table A1. (continued).

\begin{tabular}{|c|c|c|c|c|c|}
\hline $\begin{array}{l}\text { 1. Data from 1990s } \\
\text { Site }\end{array}$ & DATE & Common Name & $\delta^{15} \mathrm{~N}$ mean & $\delta^{15} \mathrm{~N}$ SD & $\mathrm{N}$ \\
\hline $3 \mathrm{~A} 15$ & Mar-1998 & Spotted Sunfish & 8.88 & 0.34 & 3 \\
\hline 3A15 & Jan-1999 & Spotted Sunfish & 8.22 & & 1 \\
\hline Cell 3 & Jan-1998 & Redeared Sunfish & 12.40 & 1.18 & 4 \\
\hline ENR-OUT & Jan-1998 & Redeared Sunfish & 11.51 & 0.97 & 9 \\
\hline U3 & Oct-1996 & Redeared Sunfish & 7.88 & 0.53 & 5 \\
\hline U3 & Sep-1997 & Redeared Sunfish & 9.70 & 4.94 & 6 \\
\hline U3 & Oct-1997 & Redeared Sunfish & 10.53 & & 1 \\
\hline U3 & Nov-1997 & Redeared Sunfish & 8.66 & 0.06 & 3 \\
\hline U3 & Jan-1998 & Redeared Sunfish & 8.70 & 0.43 & 6 \\
\hline L35B & Oct-1996 & Redeared Sunfish & 8.07 & 0.52 & 9 \\
\hline L35B & Jun-1997 & Redeared Sunfish & 7.36 & 0.38 & 2 \\
\hline L35B & Jan-1998 & Redeared Sunfish & 8.04 & 0.41 & 5 \\
\hline 2BS & Jan-1998 & Redeared Sunfish & 7.17 & 0.86 & 2 \\
\hline L67 & Feb-1997 & Redeared Sunfish & 7.70 & 0.69 & 10 \\
\hline L67 & Jan-1998 & Redeared Sunfish & 8.21 & 0.97 & 8 \\
\hline $3 \mathrm{~A} 15$ & Dec-1996 & Redeared Sunfish & 8.52 & & 1 \\
\hline $3 \mathrm{~A} 15$ & Sep-1997 & Redeared Sunfish & 7.84 & 0.19 & 4 \\
\hline $3 \mathrm{~A} 15$ & Mar-1998 & Redeared Sunfish & 8.70 & & 1 \\
\hline $3 \mathrm{~A} 15$ & Jan-1999 & Bluegill & 7.24 & & 1 \\
\hline U3 & Oct-1996 & Bluegill & 8.46 & 0.03 & 2 \\
\hline U3 & Jan-1998 & Bluegill & 9.91 & & 1 \\
\hline $3 \mathrm{~A} 15$ & Oct-1997 & Bluegill & 9.06 & 1.07 & 2 \\
\hline $3 \mathrm{~A} 15$ & Nov-1997 & Bluegill & 9.77 & & 1 \\
\hline U3 & Oct-1997 & Bluegill & 8.77 & 0.27 & 4 \\
\hline U3 & Sep-1997 & Bluegill & 9.70 & 2.99 & 9 \\
\hline $3 \mathrm{~A} 15$ & Dec-1996 & Bluegill & 9.86 & & 1 \\
\hline L35B & Jan-1998 & Bluegill & 8.83 & 0.99 & 5 \\
\hline L67 & Jun-1997 & Bluegill & 11.36 & & 1 \\
\hline L35B & Feb-1997 & Bluegill & 8.85 & 1.03 & 8 \\
\hline L35B & Jun-1998 & Bluegill & 8.97 & 1.62 & 4 \\
\hline L67 & Jan-1998 & Bluegill & 9.81 & 0.63 & 2 \\
\hline L35B & Sep-1998 & Bluegill & 10.41 & 1.64 & 9 \\
\hline L35B & Oct-1996 & Bluegill & 9.74 & 0.93 & 11 \\
\hline L67 & Nov-1997 & Bluegill & 9.70 & 0.19 & 3 \\
\hline L67 & Sep-1998 & Bluegill & 9.96 & 1.53 & 2 \\
\hline L67 & Feb-1997 & Bluegill & 8.06 & 0.93 & 9 \\
\hline Cell 3 & Jun-1998 & Bluegill & 13.38 & 1.04 & 5 \\
\hline Cell 3 & Jun-1997 & Bluegill & 12.01 & 0.62 & 2 \\
\hline Cell 3 & Jan-1998 & Bluegill & 12.53 & 0.73 & 6 \\
\hline LOX & Dec-1996 & Laregmouth bass & 9.70 & 0.36 & 36 \\
\hline LOX & Sep-1997 & Laregmouth bass & 9.28 & 0.77 & 6 \\
\hline LOX & Oct-1998 & Laregmouth bass & 8.76 & 0.63 & 20 \\
\hline Cell 3 & Oct-1996 & Laregmouth bass & 13.13 & 0.58 & 34 \\
\hline Cell 3 & Apr-1997 & Laregmouth bass & 12.84 & 0.41 & 8 \\
\hline Cell 3 & Oct-1997 & Laregmouth bass & 12.74 & 1.24 & 26 \\
\hline Cell 3 & Jan-1998 & Laregmouth bass & 11.98 & 1.25 & 2 \\
\hline Cell 3 & Aug-1998 & Laregmouth bass & 13.61 & 0.49 & 20 \\
\hline Cell 4 & Jan-1999 & Laregmouth bass & 12.61 & 0.70 & 6 \\
\hline L-7 & Oct-1996 & Laregmouth bass & 14.17 & 1.16 & 32 \\
\hline L-7 & Sep-1997 & Laregmouth bass & 15.05 & 1.47 & 20 \\
\hline L-7 & Sep-1998 & Laregmouth bass & 14.32 & 1.70 & 20 \\
\hline U3 & Oct-1996 & Laregmouth bass & 9.62 & 0.68 & 12 \\
\hline
\end{tabular}


Table A1. (continued).

\begin{tabular}{|c|c|c|c|c|c|}
\hline $\begin{array}{l}\text { 1. Data from 1990s } \\
\text { Site }\end{array}$ & DATE & Common Name & $\delta^{15} \mathrm{~N}$ mean & $\delta^{15} \mathrm{~N} \mathrm{SD}$ & $\mathrm{N}$ \\
\hline U3 & Sep-1997 & Laregmouth bass & 10.43 & 0.27 & 6 \\
\hline U3 & Oct-1997 & Laregmouth bass & 10.21 & 0.30 & 13 \\
\hline U3 & Nov-1997 & Laregmouth bass & 10.33 & 0.48 & 4 \\
\hline U3 & Jan-1998 & Laregmouth bass & 10.77 & 0.11 & 2 \\
\hline U3 & Mar-1998 & Laregmouth bass & 9.86 & 0.83 & 7 \\
\hline L35B & Oct-1996 & Laregmouth bass & 10.64 & 0.98 & 35 \\
\hline L35B & Jan-1998 & Laregmouth bass & 10.54 & 0.54 & 11 \\
\hline L35B & Sep-1998 & Laregmouth bass & 11.49 & 0.93 & 20 \\
\hline 2BS & Jan-1998 & Laregmouth bass & 10.11 & 0.50 & 10 \\
\hline L67 & Dec-1996 & Laregmouth bass & 10.30 & 0.46 & 35 \\
\hline L67 & Jun-1997 & Laregmouth bass & 10.47 & 1.82 & 5 \\
\hline L67 & Sep-1997 & Laregmouth bass & 11.75 & 1.18 & 20 \\
\hline L67 & Nov-1997 & Laregmouth bass & 10.67 & 1.24 & 8 \\
\hline L67 & Jan-1998 & Laregmouth bass & 10.61 & 1.36 & 15 \\
\hline L67 & Sep-1998 & Laregmouth bass & 11.57 & 1.14 & 10 \\
\hline L67 & Oct-1998 & Laregmouth bass & 11.47 & 0.97 & 10 \\
\hline $3 \mathrm{~A} 15$ & Dec-1996 & Laregmouth bass & 10.47 & 0.52 & 12 \\
\hline $3 \mathrm{~A} 15$ & Sep-1997 & Laregmouth bass & 9.76 & 0.50 & 18 \\
\hline $3 \mathrm{~A} 15$ & Oct-1997 & Laregmouth bass & 8.94 & 1.31 & 5 \\
\hline $3 \mathrm{~A} 15$ & Nov-1997 & Laregmouth bass & 10.55 & & 1 \\
\hline $3 \mathrm{~A} 15$ & Mar-1998 & Laregmouth bass & 9.60 & 0.95 & 6 \\
\hline LMC & Dec-1996 & Laregmouth bass & 9.92 & 0.51 & 33 \\
\hline LMC & Aug-1997 & Laregmouth bass & 10.64 & 0.16 & 2 \\
\hline LMC & Mar-1998 & Laregmouth bass & 9.84 & 0.63 & 10 \\
\hline NPC & Dec-1996 & Laregmouth bass & 11.68 & 0.11 & 5 \\
\hline NPC & Aug-1997 & Laregmouth bass & 12.46 & 0.38 & 14 \\
\hline NPC & Mar-1998 & Laregmouth bass & 11.80 & 2.66 & 16 \\
\hline Cell 3 & Oct-1997 & Florida Gar & 12.63 & & 1 \\
\hline Cell 3 & Jan-1998 & Florida Gar & 13.67 & 0.54 & 2 \\
\hline Cell 3 & Aug-1998 & Florida Gar & 13.32 & 0.71 & 4 \\
\hline ENRout & Oct-1997 & Florida Gar & 12.60 & 0.16 & 2 \\
\hline ENRout & Jan-1998 & Florida Gar & 12.06 & 0.05 & 2 \\
\hline E0 & Sep-1997 & Florida Gar & 14.99 & 1.34 & 3 \\
\hline U3 & Oct-1997 & Florida Gar & 11.17 & 0.64 & 2 \\
\hline U3 & Nov-1997 & Florida Gar & 10.95 & 0.97 & 2 \\
\hline U3 & Jan-1998 & Florida Gar & 10.69 & 0.20 & 2 \\
\hline U3 & Mar-1998 & Florida Gar & 11.09 & 0.38 & 2 \\
\hline U3 & Jan-1999 & Florida Gar & 11.00 & 0.77 & 3 \\
\hline L35B & Jan-1998 & Florida Gar & 11.88 & 0.78 & 5 \\
\hline 2BS & Jan-1998 & Florida Gar & 10.95 & & 1 \\
\hline L67 & Nov-1997 & Florida Gar & 11.75 & 1.05 & 5 \\
\hline L67 & Jan-1998 & Florida Gar & 12.21 & 0.91 & 6 \\
\hline $3 \mathrm{~A} 15$ & Oct-1997 & Florida Gar & 9.97 & & 1 \\
\hline $3 \mathrm{~A} 15$ & Nov-1997 & Florida Gar & 10.74 & & 1 \\
\hline $3 \mathrm{~A} 15$ & Jan-1998 & Florida Gar & 10.91 & 0.33 & 4 \\
\hline $3 \mathrm{~A} 15$ & Mar-1998 & Florida Gar & 10.88 & 0.90 & 3 \\
\hline $3 \mathrm{~A} 15$ & May-1998 & Florida Gar & 10.57 & 0.92 & 4 \\
\hline $3 \mathrm{~A} 15$ & Jan-1999 & Florida Gar & 9.95 & & 1 \\
\hline
\end{tabular}


J. Hong and B. Gu: Knowl. Manag. Aquat. Ecosyst. 2020, 421, 41

Table A1. (continued).

\begin{tabular}{|c|c|c|c|c|c|}
\hline $\begin{array}{l}\text { 1. Data from 1990s } \\
\text { Site }\end{array}$ & DATE & Common Name & $\delta^{15} \mathrm{~N}$ mean & $\delta^{15} \mathrm{~N}$ SD & $\mathrm{N}$ \\
\hline \multicolumn{6}{|l|}{ 2. Data from 2007} \\
\hline $\mathrm{TP}(\mathrm{ug} / \mathrm{L})$ & $\delta^{15} \mathrm{~N}(\%)$ & & & & \\
\hline 4.9 & 10.2 & & & & \\
\hline 7 & 8 & & & & \\
\hline 8.5 & 9.1 & & & & \\
\hline 15 & 11.3 & & & & \\
\hline 24.5 & 13.1 & & & & \\
\hline 42.1 & 14.2 & & & & \\
\hline 46.5 & 14.5 & & & & \\
\hline
\end{tabular}

